\title{
BUILDING COALITIONS: Networking
}

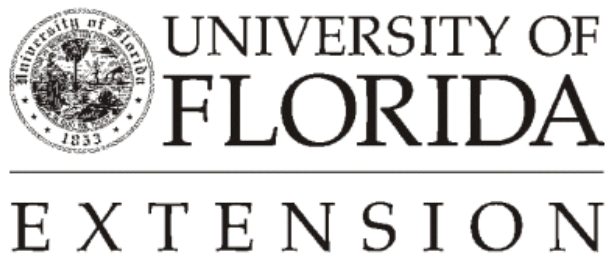

Institute of $\mathbf{F}_{\text {ood and }} \mathbf{A}_{\text {gricultural }} \mathbf{S}_{\text {ciences }}$ 
In today's world of constant change individuals need to know where to go, who to contact, how to obtain information and resources to achieve a specific goal. This can be done through networks and coalitions.

\section{Networks}

A network consists of individuals or organizations who share information, ideas, resources or goals to accomplish individual or group goals. (Jackson 1991) Networking is a process of acquiring resources and building power by using or creating linkages between two or more individuals, groups, or organizations. It provides a valuable tool for getting things done. (Wells 1989) Information and resources are obtained from others and it is the lack of information and resources that hinders us.

\section{Getting Started}

We network every day of our lives whether it's informal or formal. If one individual lacks the information you are seeking he or she can refer you to another individual. The more individuals you know the more individuals will know you, the greater the probability of accomplishing your goals. Your visibility increases and your network of individuals increases. The aim is to meet as many individuals as possible.

As you network with individuals you will need some basic tools such as (1) an address book or Rolodex to record and keep track of contacts' addresses, notes of meetings, commitments and any detail information, (2) an appointment calendar to set up meetings, (3) business cards that contain fax number and electronic mail address.

\section{Using and Expanding Networks}

Decide whether your current goal is money, power, or social. Examine your list and contact the most powerful and influential individual to help achieve your goal. During your networking discuss what you have in common, your skills, type of information you are seeking and available resources. The more you share ideas, the more you will increase your potential clout.

Another aspect of networking is involvement in professional associations that can provide a wide range of contacts. Attend as many association meetings and conferences as possible. Make yourself visible and establish a reputation. Circulate at the meetings and exchange business cards, talk to everyone you know and meet new contacts. Afterward, follow-up with a phone call or note. Also Participate in organizations other than professional associations where you can develop a wide range of contacts with people who share your ideas and concerns. Remember it's a two way street.

You may want to establish a formal network with a specific interest or field. This can provide opportunities to meet individuals with a broad range of experiences and expertise, obtain current information, meet specialists in the field and develop friendship. 


\section{Summary}

We can have a greater impact on our goals by using networks and coalitions as major tools to multiply our power and efforts. If you network with ten individuals and those ten network with ten more, you have increased the number of individuals with whom you can exchange information and resources from ten to one hundred. We can do a great deal when we join efforts with those of other individuals. 


\section{References}

Downey, Peg. "Multiplying Power: The Use of Networks and Coalitions." In Networking, edited by Mary Scott Welsh. New York: Harcourt, Brace, Jovanovich, Inc., 1980.

Hart, Thomas E. Building Coalitions for Support of Schools. Oregon School Study Council. September 1988.

Jackson, Daney and William Maddy. "Introduction," Building Coalitions Fact Sheet, Columbus: The Ohio Center for Action on Coalitions, Ohio Cooperative Extension Service, The Ohio State University, 1991.

Levin, Edward and R. V. Denenberg. Alliances and Coalitions: How to Gain Influence and Power by Working with People. New York: McGraw-Hill Book Company, 1984.

Lipnack, Jessica and Jeffrey Stamps. Networking: The First Report and Director. Garden City, N.Y.: Doubleday, 1982.

Lipnack, Jessica and Jeffrey Stamps. The Networking Book. New York, N.Y.: Routledge and Regan Paul, 1986.

Loughran, Elizabeth Lee, "Networking, Coordination, Cooperation and Collaboration, Different Skills for Different Purposes." Community Education Journal. July 1982.

Mueller, Robert K. Corporate Networking: Building Channels for Information and Influence. New York: The Free Press, 1986.

Raye-Johnson, Venda. Effective Networking. Library of Congress Catalog Card Number 89-81951, 1990.

Wells, Betty L. "Module 5: Working with Groups and Organizations." Working with Our Public. North Carolina Agricultural Extension Service, 1989.

\section{Author}

Vicki Braddy, Administrative Assistant, The Ohio Center for Action on Coalitions, Ohio Cooperative Extension Service, The Ohio State University.

C) 1992 The Ohio State University 
This series on Coalition Building was developed by The Ohio Center For Action on Coalition Development for Family and High Risk Youth, Richard Clark, Ph.D., Director. It has been adapted for County Extension Faculty in Florida to facilitate work with local and regional organizations and groups such as non-profits, cooperatives, county extension associations, and others that might benefit from a plan for working together to achieve support for mutual goals.

This document is FY503, Part 11 of the 16 part series adapted for use in Florida by Elizabeth B. Bolton, Professor, Community Development and Lisa Guion, Assistant Professor, Program Planning and Evaluation; Department of Family, Youth and Community Sciences, Florida Cooperative Extension Service, Institute of Food and Agricultural Sciences, University of Florida, Gainesville, 32611-0310.

Reprinted with permission March, 1997. Revised April, 2002.

The Institute of Food and Agricultural Sciences is an equal opportunity/affirmative action employer authorized to provide research, educational information and other services only to individuals and institutions that function without regard to race, color, sex, age, handicap, or national origin. For information on obtaining other extension publications, contact your county Cooperative Extension Service office.

Florida Cooperative Extension Service/Institute of Food and Agricultural Sciences/University of Florida/Christine Taylor Waddill, Dean 